\title{
Some suggestions for Urban planning approach to Green Infrastructure, implications for Vinh city, Nghe An province, Viet Nam
}

\author{
Kieu-Vinh Nguyen-Thi ${ }^{*}$, Thuy-Huong Doan-Thi ${ }^{1}$ \\ ${ }^{1}$ Department of Civil Engineering, Vinh University, 182 Le Duan Str., Vinh City, Nghe An Province, \\ Vietnam
}

\begin{abstract}
Research on green infrastructure has become a mainstream of managers, planners and architects around the world given its utmost impacts on human life and nature. Green infrastructure protection and development in urban management, planning, design and construction represents an important task to ensure sustainable development. This article presents some suggestions for urban planning approach to green infrastructure, contributing to the protection and development of this system.
\end{abstract}

\section{Introduction}

Green infrastructure is a planning network connecting multi-functional green spaces to protect natural habitats and biodiversity, capable of coping with changes to the climate and other biospheres, capable of creating healthy and sustainable lifestyles, enhancing the wellbeing of urban dwellers, improving access to leisure and green assets, supporting the rural and urban economy, and better supporting planning and management of green corridors and spaces in the long run[1-7]

Green infrastructure consists of many elements that work together to maintain the network of natural processes. These elements are divided into:

- Open spaces: Large parks, natural forests, planted forests, free open spaces, nature reserves, lakes and ponds, natural areas and historical relics that have been zoned for protection, public spaces and squares accessible to rural areas, etc.

- Linkage strips: corridors of canals and rivers, trails, pedestrian and bicycle paths, green corridors, among others.

- "Green city" elements: individual small parks, private gardens, street greenery, wall and roof gardens, rainwater collection and infiltration systems (rain gardens, ecological sidewalks, lowland strips, artificial wetlands), porous and water-absorbent hard paved surfaces (roads, pavements, parking lots, etc.), rainwater collection and storage equipment, low energy or renewable energy equipment, etc. [7].

Below are the authors' suggestions for urban planning approach to green infrastructure, implications for Vinh city, Nghe An province, Viet Nam

\footnotetext{
* Corresponding author: kieuvinhkxd@vinhuni.edu.vn
} 


\section{Key principles}

\subsection{Part of urban master plan}

The long-term urban master plan is built upon various field surveys, the most important of which is green infrastructure planning. Therefore, green infrastructure planning must be done before the urban master plan is developed.

The green infrastructure master plan must aim to protect natural functions and ecological processes, taking into account productive lands or open spaces that benefit people. In particular, it is necessary to focus on the landscape conservation areas and adjacent areas (forests, rivers, fields, swamps, etc.). These factors are seen as the foundation of green infrastructure because they perform the main function of the ecosystem. Sharing a key role in the region's supporting natural system, they need to work together to maintain the value and function of the entire ecosystem, meaning there is a need for connectivity among these important areas. The development of the interconnected network requires the use of a framework of hubs/corridors and incorporates a diverse range of land uses. Network design standards need to be established on the basis of ecology and land-use planning theory and align with the surrounding landscapes. The level of protection for areas in the connected network of green infrastructure should be determined and included in the analysis model. In addition, connected network can be analyzed to identify gaps for policymakers, planners, and designers to work hard towards recovery. The recovery of lost hubs/corridors is crucial to any green infrastructure planning, which means the network connecting green infrastructure established needs to contain at least the altered or deteriorated areas. The final connected network planning design should be described in geographical terms (maps). [8]

Opportunities for prioritized protection represent another requirement of green infrastructure planning. When designing a connected network, it is necessary to highlight land protection levels and other determinants through the goal-setting process to identify priorities to rank and prioritize elements for conservation. Green infrastructure planning does not only involve establishing a connected network, but also providing a list of land elements to be protected and identifying sources for the targeted funding plan. Good green infrastructure planning needs to map out the areas for recovery in the appropriate protection strategy with the implementation tools and funding in different spaces outlined in the network design of green infrastructure.

However, direct guidance from the executive council or advisory committee is required to plan and develop such green infrastructure. The executive council must include all relevant members in the entire area for green infrastructure research and development (i.e. entire city and adjacent neighborhoods). A feasible green infrastructure requires consensus, support and participation not only at all levels of government, community, but also by private owners because many green infrastructure elements may be located on the land they own.

\subsection{Part of the detailed master plan of urban functional zones}

Detailed planning of urban functional zones must be in line with the urban green infrastructure master plan, socio-economic development master plan and the urban development master plan as a whole. Comply with the norms, technical regulations, and technical standards adopted by the State and the industry in organizing the planning of urban functional zones. Create modern, civilized urban functional zones, rich in indigenous cultural identity and sustainable development. 
Reasonable location of urban functional zone planning is reflected through how the city's land resources are used, the connection of such functional zone with surrounding areas, other functional zones and the city center. [10-11]

To build an urban functional zone, it is necessary to change the existing natural morphology due to excavation, leveling, relocation, encroachment, etc. These activities are indispensable but must be "nature-based" to ensure the inherent ecological balance, respect the natural environment and minimize encroachment, thereby protecting the natural environment from fragmentation and establishing a connected network instead. The leveling and relocation of low-lying lands, canals, ponds, etc. to build works without replenishing with other ecological lakes or new drainage canals will result in inundation. The use of large groundwater resources without natural replenishment combined with surface concreting prevents rainwater from seeping into the ground, further depleting groundwater and causing subsidence. Excessive intervention will deform nature, affect natural processes and lead to unpredictable consequences. One of the most important mechanisms of nature and human body is the ability to protect, regenerate, and balance by itself. One of the principles for sustainable urban development is to ensure this factor. Because once this ability is lost, it will take substantial efforts and finance to help nature restore its function, if at all possible.

The size of an urban area needs to ensure a fine balance among population, area and functional elements of the urban area. Ensure reasonable population density which is aligned with the urban loading capacity, reduce mechanical and natural population growth. This helps to meet citizens' daily needs with environmental, ecological and social services. Plan urban development while maintaining an optimal balance among urban population development, environmental and natural resource preservation. Land use diversification also helps to minimize waste, diversify residential and public housing types, make the city adaptive to economic development and growing workforce, so that people can easily access life services. Public housing can be combined with open spaces and entertainment for the public while residential areas can enhance community spaces, minimize motor vehicle transport and enhances walkways and bike paths for the public, etc. Planning of urban functional zones should promote open spaces, urban water surface, greenery systems, green roofs and green walls, non-motorized roads, vegetation cover, ecological pavements, environment-friendly materials, rainwater collection devices, renewable energy equipment, etc.

Urban infrastructure is often man-made with diminishing natural factor. More manmade infrastructure represents greater grandeur of the city. However, excessive surface concretization is also one of the main causes of urban inundation, preventing rainwater from seeping into the ground and creating a large amount of overflow rainwater. Lawns, bushes, gardens, lowlands, and the like are areas that absorb and retain rainwater very well, $1 \mathrm{~m} 2$ of bare land can absorb $2.5 \mathrm{~m} 3$ of rainwater. Surface concretization and excessive use of advanced materials such as glass, steel, stainless steel, composite, etc. for buildings also cause urban heat island phenomenon where urban temperature is often $2-3 \mathrm{oC}$ higher than that in the countryside. Therefore, it is necessary to increase the use of local materials that are friendly to people and the natural environment. The construction of many buildings, especially high-rise buildings in urban areas, leads to the massive consumption of electricity and water. This highlights the necessity to limit the construction of high-rise buildings and design in the "open" direction to make the best use of nature such as bringing natural wind and natural light into the house; planting many trees, creating green walls, green roofs; use less heat absorbing materials to reduce air conditioning - a factor that raises urban temperatures. Water conservation is also an important criterion for a sustainable ecocity. Economical use of water and reuse of these water sources by filtration and jacuzzi 
systems will help to reduce water supply required for the city. After being cleaned, used water can be utilized to wash cars, water the plants, etc. [12-16]

Today, energy efficiency, clean energy, and renewable energy (considered as infinite energy source for human beings) has become the goal of the entire mankind since these are energy sources to reduce greenhouse gas emissions, the decisive factor to climate change that contributes to protecting the environmental and keeping the earth green. Renewable energy sources include solar energy, water, geothermal, wind, biomass energy. Therefore, when planning urban functional zones, we need to pay attention to energy supply and use for buildings to move towards sustainable development.

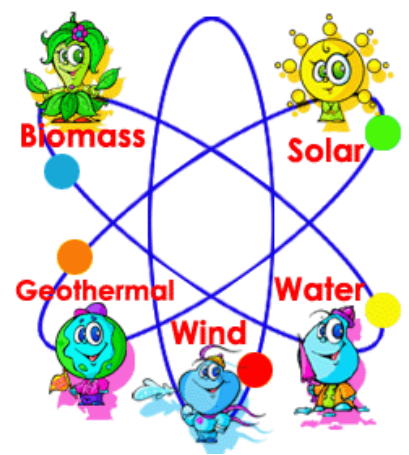

Fig.1. Potential renewable energy sources

\section{General viewpoints}

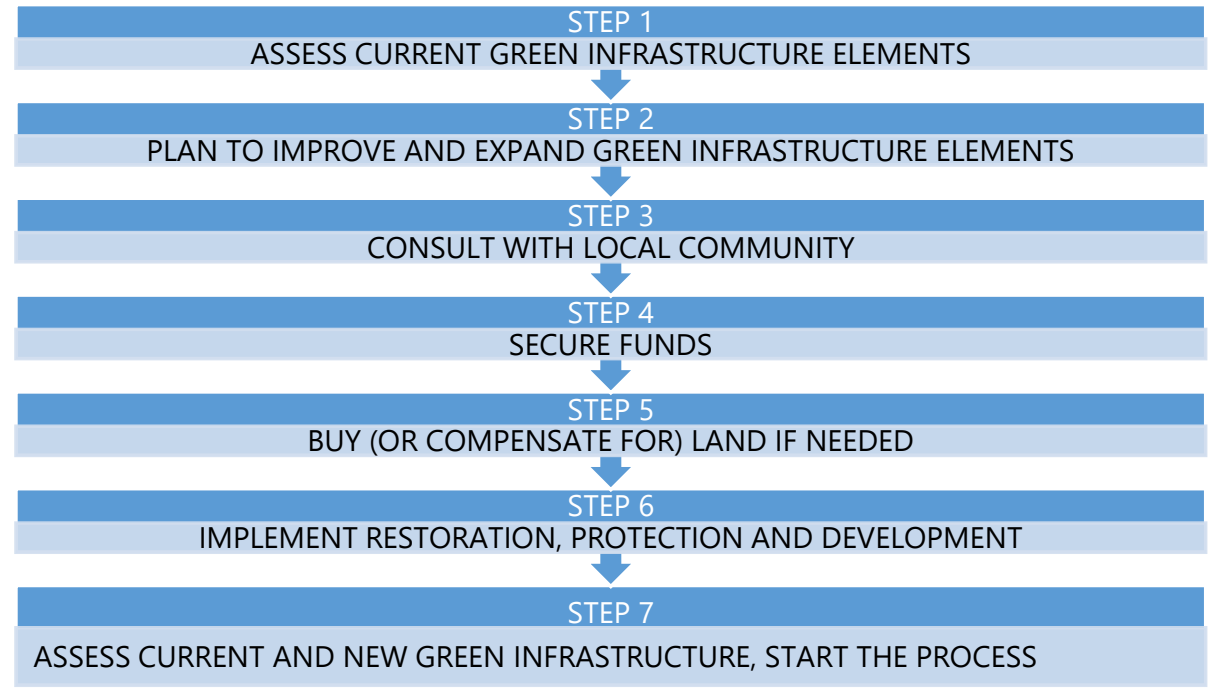

Fig. 2. Diagram of the steps for successfully developing green infrastructure [author]

To plan, design, and successfully develop urban areas with green infrastructure approach, it is necessary to base on the above fundamental steps.

Figure 2 provides policymakers and planners with stages through which they can assess local resources and discuss how to best develop with a green infrastructure approach. It also shows that securing land and funding is an essential element of that process. 


\section{Some proposed solutions for urban planning with green infrastructure approach, implications for Vinh city, Nghe An province, Viet Nam}

- Identify important natural open spaces or design locations for central open spaces of urban functional zones. As part of the study on the natural conditions of Vinh City, green infrastructure elements in alignment with the master plan to 2030 and in connection with other elements in adjacent areas have been collected, analyzed, compared, and synthesized, including natural elements such as Lam river, Vinh river, lakes, canals, paddy land, lowland, Quyet mountain forest, Hung Hoa mangrove forest; man-made public open spaces such as Ho Chi Minh Square, Central Park, Nguyen Tat Thanh Park, Cua Nam Park, Ancient Citadel Park, etc.; historical and spiritual relics such as temples, pagodas, shrines, churches, and the list goes on. Asset elements of Vinh City's green infrastructure have been mapped to propose zoning for protection while restoring and developing areas that have been affected by human activities. [17]

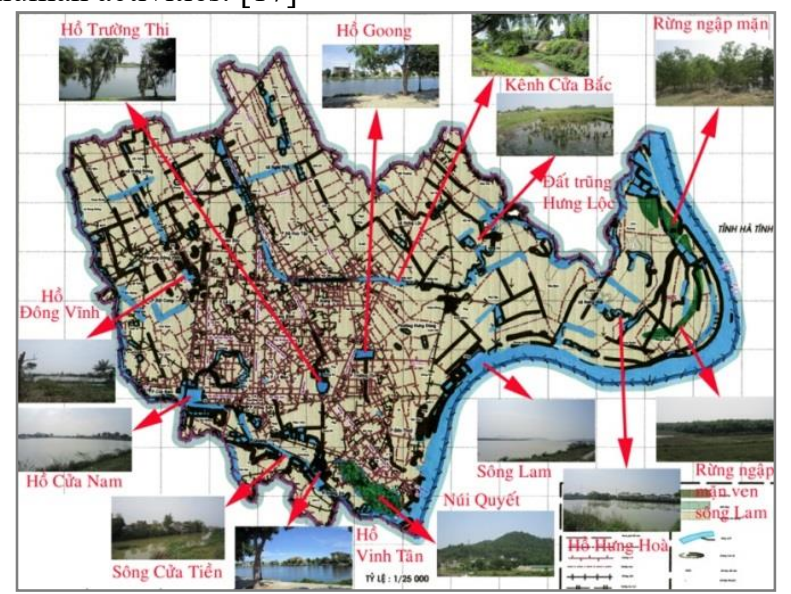

Fig. 3. Map identifying asset elements of Vinh City's green infrastructure in the current administrative boundaries

- Develop a green corridor based on existing natural elements or a new design to connect the central open spaces and with other open spaces of the adjacent areas.

- Develop a green transport factor that ensures human participation in that connectivity system without affecting them (walking paths, bike paths, trails, waterways, etc.). 


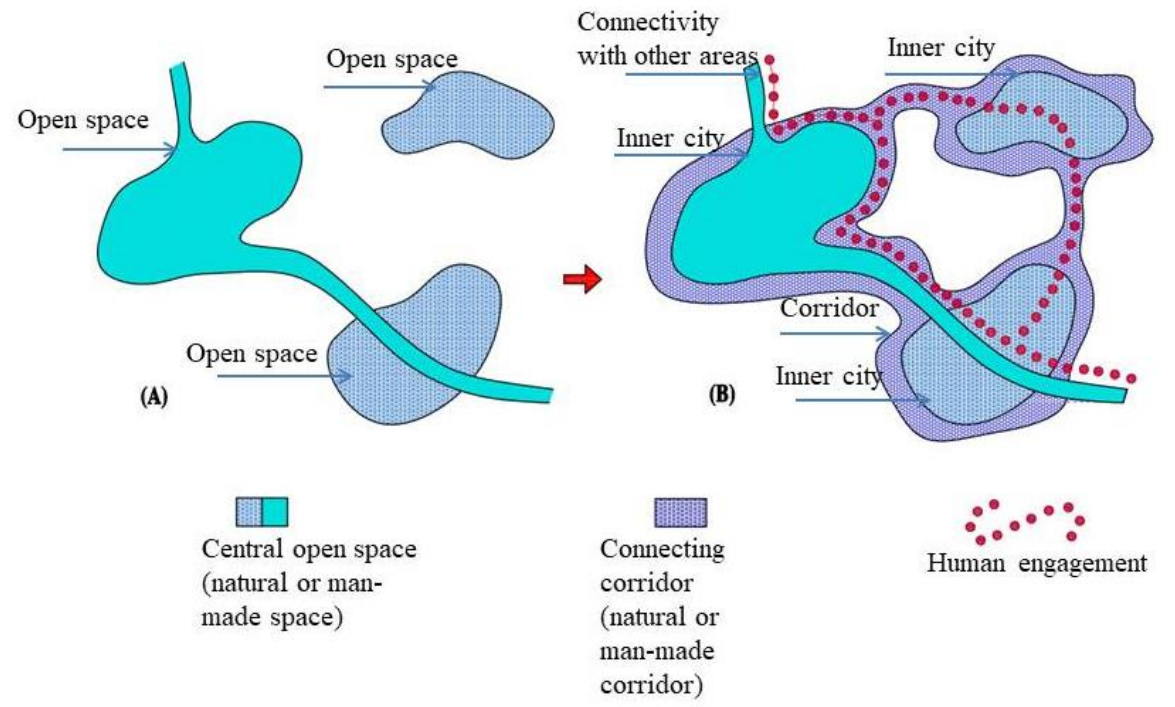

Fig. 4. Define open spaces (A) and establish connectivity systems (B)

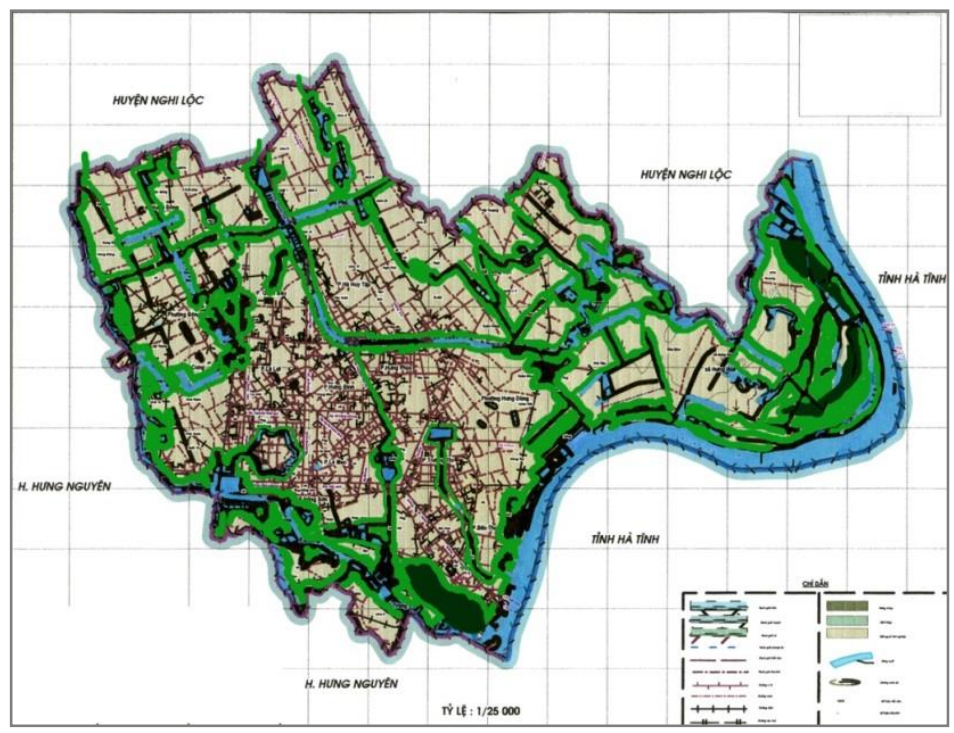

Fig. 4.3. Connectivity network master plan of Vinh City's green infrastructure in the current administrative boundaries

- Vinh city's development master plan to 2030 clearly identifies Vinh as a river city, built upon inherent characteristics of green impression which connects public spaces and develops a system of lowlands and highlands, enabling the city to act as a sponge for seasonal flood management.

- Utilization of agricultural land and crops should be minimized.

- Minimize the encroachment and fragmentation of natural ecological areas in the planning of urban functional zones while implementing improvement and development solutions to mitigate the degradation of the ecosystem, biodiversity and natural processes. 


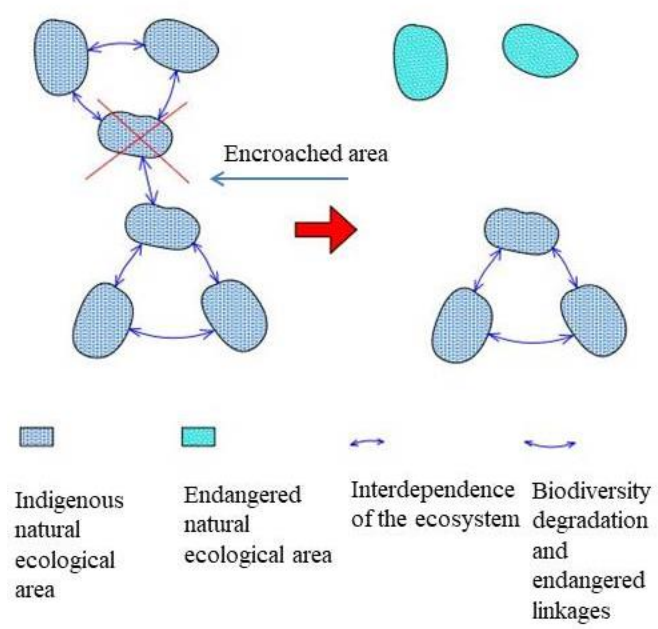

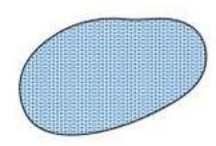
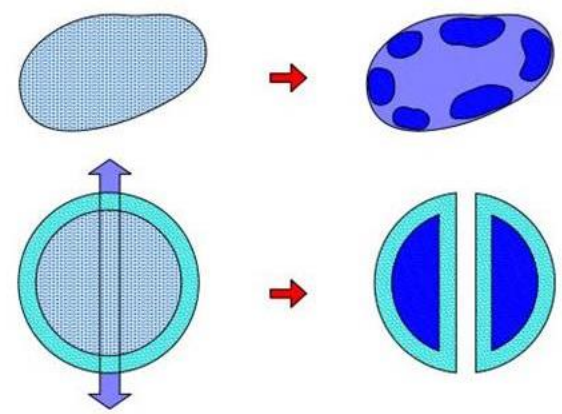

Natural area

(vast,

indigenous)

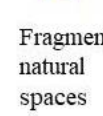

Other

constructed Margina

elements

(man-made

infrastructure

Fig. 5. Impacts of encroachment and fragmentation of the ecological environment in construction planning

- The proposed planning solutions should pay attention to the relationships with adjacent areas so that green infrastructure approach can maintain connectivity (Figure 6).

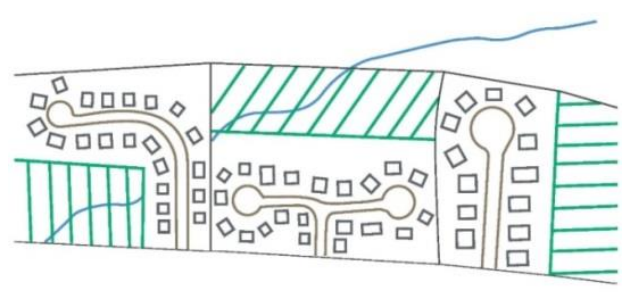

a)

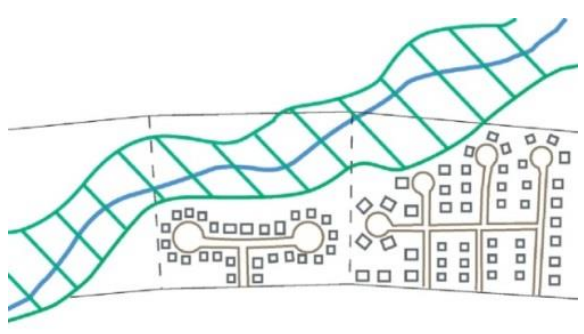

b)

Fig. 6. Impacts of planning solutions on urban green infrastructure [5] a - Environmentally unsound planning solutions

$\mathrm{b}$ - Planning solutions in the direction of developing green infrastructure

- Properly pay back to nature when there is no choice but to invade their spaces through the development of open spaces, ecological ponds, lakes, canals, etc. [19]

Functional zoning plan should be based on existing infrastructure while respecting existing natural, semi-natural and artificial infrastructure elements. Based on the natural and climatic characteristics of Vinh City, trees with wide canopy and low deciduosity, no/less pests, non-toxicity, and ability to withstand hot weather, storms, and strong winds such as Indian almond, crape myrtle, royal poinciana, wutong, dry zone mahogany, mango, whistling pine tree, eucalyptus, areca, coconut, etc. The tree stumps should not be surrounded by hard edges and separating paved surfaces (of brick and concrete) as popular today, but should be left open instead to enhance absorption of rainwater and reduce rainwater runoff which causes flooding for the city. [18] 
- Diversify land use to help people access daily life services within walking, cycling and public transport capacity to minimize the use of motor vehicles. [20]

- Ensure urban climatic conditions, make use of favorable wind directions, minimize adverse wind directions, and secure environment. Given natural and climatic conditions of Vinh City with a long hot season with abundant radiation energy, there are two typical monsoons, namely the Southwest wind or dry wind which appears during May to September and the Northeast wind which lasts from October to April next year. Therefore, it is best positioned to utilize solar and wind energy so that the architectural works here can run on solar and wind energy while the national power grid can serve as backup during bad weather, rainy season when solar panels produce no or lower power output or when the wind speed is not sufficient. When organizing the architectural planning of urban functional areas for Vinh City, in addition to ensuring the best ventilation and natural light for buildings' energy efficiency, it is also possible to place solar panels and wind turbines directly on the rooftops of buildings, thereby providing electricity for such works. These energy sources can also be used for lighting and other functions of public spaces. Construct wind and solar energy plants in locations to the West and East of the city where these energy sources can be best leveraged. [17]

- Pay attention to the differences in construction layout and density to create open spaces and meet people's needs with multi-functional and green infrastructure approach

\begin{abstract}
Green space in the form of narrow corridors, often formed after planning (remaining space)
\end{abstract}

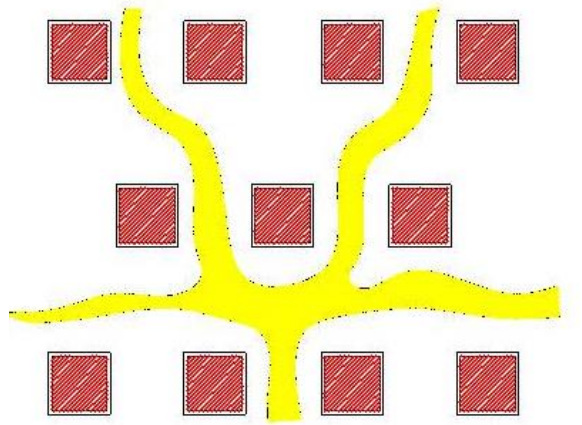

Inadequate to meet human demands, limited aesthetic quality and role with nature
Green space solutions embedded right from the early stage of planning, an important space in the new development trend

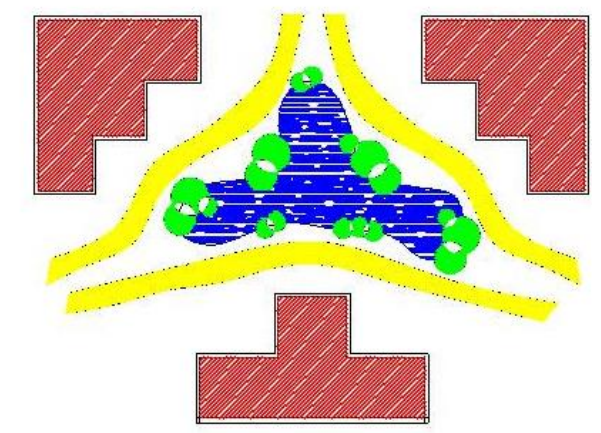

Multifunctional to meet human demands, significant aesthetic quality and role with nature

Fig. 7. Impacts of construction layout and density on the creation of multi-functional open spaces

with green infrastructure approach [author, 6]

\section{Conclusion}

Altering nature to develop man-made infrastructure for human life is an inevitable process. However, minimizing adverse impacts of these processes while respecting inherent laws of nature has become a mainstream research topic in urban management, planning and design in the world today. Studies on green infrastructure have identified the functions, roles and important benefits of this system for human and natural life, ensuring sustainable development. Therefore, urban development should aim towards sustainability built on the foundation of green infrastructure.

Above are some basic proposals on principles and perspectives for urban planning with green infrastructure approach implications for Vinh city, Nghe An province, Viet Nam. To 
protect and develop the green infrastructure, it is necessary to have a master plan on the green infrastructure before developing the urban development master plan. However, green infrastructure varies across different regions, so it is necessary to have more in-depth studies on the theory of green infrastructure as a scientific basis for concrete and effective solutions applicable to each metropolitan area.

\section{References}

1. Benedict. MA \& McMahon. ED, Renewable Resources Journal, Volume 20, Number3, Autumn (2002).

2. Benedict. MA \& McMahon, ED, Green Infrastructure: linking landscapes and communities, Island Press, Washington, (2006).

3. Countryside Agency, Countryside In and Around Towns: The Green Infrastructure of Yorkshire and the Humber, Countryside Agency, Leeds, (2006).

4. Department of Agriculture and Consumer Services, Florida Division of Forestry, West Florida Regional Planning Council, Northwest Florida Green Infrastructure Design.

5. Green Infrastructure Center, Green Infrastructure Principles and Planning Tools, Richmond Regional Project Mini Workshops (2009).

6. Natural England, Green Infrastructure Guidance, (www.naturalengland.org.uk).

7. Nguyen Thi Kieu Vinh, Understanding the concept of green infrastructure, ISSN Journal 1859 - 2228 Vinh University, page 85, volume 43, Issue 2A, 2014.

8. Williamson, KS, Growing with Green Infrastructure, Heritage Conservancy, Doylestown, PA, (2003).

9. Botequilha Leitão, A \& Ahern, J (2002), Applying landscape ecological concepts and metrics in sustainable landscape planning. Landscape and Urban Planning.

10. CABE Space (2003), Planning green infrastructure. CABE Space, London.

11. US army Corps of engineers (December 2009), Green infrastructure design, Using Low Impact Development.

12. Office of the Deputy Prime Minister (2005), Creating Sustainable Communities: Greening the Gateway Implementation Plan.

13. Landscape Institute (2009), Green Infrastructure: connected and multifunctional landscapes - position statement. The Landscape Institute, London.

14. Ismail Said and Mazlina Mansor Universiti Teknologi Malaysia and International Islamic University Malaysia (21 July 2011), Green infrastructure in cities and towns in southeast asian countries: Quest for research.

15. Ahern, J (2007), Green infrastructure for cities: The spatial dimension. In: Novotny, V \& Brown, P (Eds.) (2007), Cities for the Future Towards Integrated Sustainable Water and Landscape management.

16. Ahern, J (2007), Green infrastructure for cities: The spatial dimension. In: Novotny, V \& Brown, P (Eds.) (2007), Cities for the Future Towards Integrated Sustainable Water and Landscape management.

17. Nguyễn Quang Hồng (2003), TP Vinh quá trình hình thành và phát triển (1804 1945), Nhà Xuất bản Nghệ An.

18. Phạm Đức Nguyên (chủ biên) (2002), Các giải pháp kiến trúc khí hậu Việt Nam, Nhà xuất bản Khoa học và Kỹ thuật. 
19. Davies, C, McGloin, C, MacFarlane, R \& Roe, M (2006), Green Infrastructure Planning Guide Project: Final Report. NECF, Annfield Plain.

20. Fábos, JG (1995), Introduction and overview: the greenway movement, uses and potentials of greenways. Landscape and Urban Planning. 